\title{
Standards for Methods Utilizing Environmental DNA for Detection of Fish Species
}

\author{
Lu Shu ${ }^{1}$, Arne Ludwig $2,3, * \mathbb{C}$ and Zuogang Peng ${ }^{1, *(\mathbb{C}}$ \\ 1 Key Laboratory of Freshwater Fish Reproduction and Development (Ministry of Education), \\ Southwest University School of Life Sciences, Chongqing 400715, China; shulu331@email.swu.edu.cn \\ 2 Department of Evolutionary Genetics, Leibniz-Institute for Zoo and Wildlife Research, \\ 10315 Berlin, Germany \\ 3 Albrecht Daniel Thaer-Institute, Faculty of Life Sciences, Humboldt University Berlin, 10115 Berlin, Germany \\ * Correspondence: ludwig@izw-berlin.de (A.L.); pzg@swu.edu.cn (Z.P.)
}

Received: 20 January 2020; Accepted: 7 March 2020; Published: 11 March 2020

\begin{abstract}
Environmental DNA (eDNA) techniques are gaining attention as cost-effective, non-invasive strategies for acquiring information on fish and other aquatic organisms from water samples. Currently, eDNA approaches are used to detect specific fish species and determine fish community diversity. Various protocols used with eDNA methods for aquatic organism detection have been reported in different eDNA studies, but there are no general recommendations for fish detection. Herein, we reviewed 168 papers to supplement and highlight the key criteria for each step of eDNA technology in fish detection and provide general suggestions for eliminating detection errors. Although there is no unified recommendation for the application of diverse eDNA in detecting fish species, in most cases, 1 or $2 \mathrm{~L}$ surface water collection and eDNA capture on $0.7-\mu \mathrm{m}$ glass fiber filters followed by extraction with a DNeasy Blood and Tissue Kit or PowerWater DNA Isolation Kit are useful for obtaining high-quality eDNA. Subsequently, species-specific quantitative polymerase chain reaction (qPCR) assays based on mitochondrial cytochrome $b$ gene markers or eDNA metabarcoding based on both $12 S$ and $16 S$ rRNA markers via high-throughput sequencing can effectively detect target DNA or estimate species richness. Furthermore, detection errors can be minimized by mitigating contamination, negative control, PCR replication, and using multiple genetic markers. Our aim is to provide a useful strategy for fish eDNA technology that can be applied by researchers, advisors, and managers.
\end{abstract}

Keywords: environmental DNA; water sampling; eDNA capture; eDNA extraction; eDNA detection; genetic marker; detection error

\section{Introduction}

Environmental DNA (eDNA) is a newly developed and promising resource for species detection [1,2]. In contrast to DNA collected directly from organisms, eDNA is obtained from water, sediments, soil, or ice of various environmental samples [3-5] and reveals important information about past and present biodiversity [6]. eDNA from aquatic ecosystems is suitable for diversity assessment of contemporary aquatic species [7]. Furthermore, emerging eDNA technologies are non-invasive, sensitive, and cost-efficient compared to traditional survey approaches [2,5,8]. Target organisms can be detected at any life stage, including in the egg, larval, and juvenile forms from eDNA samples. Recently, eDNA was used to detect the critically endangered Mekong giant catfish Pangasianodon gigas [9] and rare green sturgeon Acipenser medirostris, demonstrating that the method is applicable for detecting rare fish species even in large river systems $[10,11]$. 
The promising applications of eDNA for monitoring aquatic biodiversity including fishes or their communities have been extensively reviewed [1,2,5,8,12-23]. With respect to eDNA, fish are currently the most studied group of macro-organisms in aquatic ecosystems [24]. Various eDNA protocols for detecting fish among different groups and habitats have been developed (see below). The process of developing eDNA techniques for aquatic organism detection has also been detailed in literature $[1,19]$. The first study of eDNA in fish revealed the presence of two invasive species of Asian carps in river ecosystems [25]. The methods used in the study were later developed to detect invasive or endangered species by conventional polymerase chain reaction (cPCR), quantitative PCR (qPCR), or digital droplet PCR (ddPCR) [26-28]. With advancements in high-throughput sequencing (HTS), additional applications have focused on assessing fish species richness through metabarcoding $[29,30]$. Consequently, the potential applications, cost-effectiveness, and evident simplicity of eDNA technology have made this approach extremely popular for fish detection.

Although Lear et al. [31], Kumar et al. [32], and Tsuji et al. [24] have summarized various protocols for each step in eDNA methods for aquatic organism detection and proposed standards or guides in the field, such criteria are not specific to fish detection and lack quantitative standards for general situations. Because fishes have been identified as the taxonomic group with greatest research interest in the context of eDNA, it is important to determine appropriate standards for fish eDNA surveys [33]. To supplement and publicize these standards, we describe the key criteria in this review.

This review provides an overview of eDNA research including experimental and field studies of fishes performed for over a decade. We utilized "environmental DNA" and "fish" as keywords during a literature search on Web of Science. We manually filtered the papers using the criteria described by Tsuji et al. [24] and excluded review papers. The literature search was completed on 19th June 2019; a total of 168 research articles from 2011 to 2019 were included. We summarized detailed information from all papers (Table S1) and recorded technical protocols associated with each step of fish eDNA detection (Table S2). Based on this information, the frequency and proportion of use of each protocol were calculated from the 168 eDNA studies (Figures 1-4).

\section{Criteria for eDNA Sampling, Capture, and Extraction Strategies}

\subsection{Sample Volume, Depths, and Amount of Water}

There are no general guidelines for sample volume, depths, and amounts of water. These factors must typically be considered according to the purpose of study, size and quality of the water body, potential abundance of target species, and subsequent steps of eDNA analysis. In fish eDNA detection, samples are collected from diverse water sources including artificial or experimental sources, ponds, lakes, streams, rivers, and seas and are obtained from different depths including the surface, middle, bottom, or others (Table S2). Sample volumes vary from $1.5 \mathrm{~mL}$ [34] to $45 \mathrm{~L}$ [35]. However, 1 or $2 \mathrm{~L}$ is typically collected from the field (Table S2). The standard volume of 1 or $2 \mathrm{~L}$ of water is most commonly utilized for filtration and concentrating DNA from water samples (Table S2). An appropriate sampling depth improves species detection, which should differ between lotic (e.g., stream) and lentic (e.g., lake) ecosystems. For example, streams tend to have a turbulent flow with well-mixed water; thus, surface water samples can be used for eDNA detection in streams [36]. Lake stratification can lead to differences in the depth at which a sample is collected; thus, pooling different layers of water for each sample containing at least upper and lower water is recommended to reduce sampling bias for diversity assessment in lentic systems [37]. The sample volume depends on the size of the water body and abundance of the target species. If the surveyed water body is a large lake (e.g., a lake with a surface area of 535 ha [38]) or coastal sea [39], more samples must be collected to include more eDNA molecules. If the target species is widely distributed or has low abundance, the sampling range and volume should also be expanded to capture as many of the target species as possible [40]. Information about the ecology (e.g., feeding areas or spawning grounds) of target species should be used for sampling. Field sample replicates are necessary to enhance the efficiency of DNA collection 
and probability of target eDNA detection; at least three samples were collected from each site in most studies [38,41-45]. When the number of samples is increased, to improve work efficiency and reduce analysis cost, researchers may consider pooling the water samples from multiple locations for subsequent processing. However, Sato et al. [46] and Zhang et al. [47] demonstrated that pooled samples decreased species detection compared to using individually processed samples, indicating that sample pooling is not useful for assessing fish assemblages. Thus, we do not recommend pooling samples for subsequent analysis. In addition, for lentic systems such as lakes, shoreline sampling with surface water can capture most fish species eDNA [47]. We recommend that shoreline sampling can be used to briefly survey lentic systems, whereas systematic spatial sampling should be used in subtle spatial distribution pattern surveys for entire fish species in large lentic systems (e.g., a lake with a surface area of 4343 ha [47]).

\subsection{Methods of eDNA Concentration}

The methods of eDNA concentration involve centrifugation, isopropanol or ethanol precipitation, and filtration. Centrifugation and precipitation are generally suitable for collecting small volumes such as $1.5 \mathrm{~mL}$ [34] or $15 \mathrm{~mL}$ [48] of water, whereas filtration can handle larger bulk volumes from $250 \mathrm{~mL}$ to $45 \mathrm{~L}$ of water (Table S2). Filtration of a large volume of water can improve the detection of rare species, and preservation of the filters is more convenient than using water samples; hence, filtration methods have become the most widely used methods for fish eDNA capture from water samples. Filtering on-site is beneficial for eDNA preservation because it prevents eDNA decay during transportation, whereas filtering in a laboratory can save field time and eliminate field contamination. Based on the specific survey water and field conditions, one filtration strategy can be chosen. When the water has low turbidity, number of samples is small, and portable pump has enough power to process samples, we recommend on-site filtration [36,49]. When sampling turbid water or the sample number is large, water samples should be transported back to the laboratory in a sterile bottle for filtration $[50,51]$. Additionally, we recommend water sample transport under dark conditions because ultraviolet (UV) light is damaging to DNA. Because of the difficultly in achieving refrigeration or freezing in the field, we recommend using a liquid preservative (e.g., ethanol [52]) to store eDNA on filters or water samples at room temperature. Most studies suggest that the sampling to filtering steps should be conducted within $24 \mathrm{~h}$ of collection (Table S2). At a remote survey site, water samples should be filtered locally rather than transported back to the main laboratory, which also reduces transportation costs [53]. Furthermore, enclosed capsule filters (e.g., Sterivex ${ }^{\mathrm{TM}}$-GP unit [54]), which are not opened in the field or in some cases not even in the laboratory, is a good choice for the collection and transportation of field water samples, reducing contamination throughout eDNA sampling.

\subsection{Selection of Filters for Fish eDNA Capture}

Various pore sizes and materials for filter types have been reported (Table S2). The reported pore sizes of filters vary from $0.2-180 \mu \mathrm{m}$, and the most commonly used pore size is $0.45 \mu \mathrm{m}$ (Table S2; Figure 1a). It was reported that 1-10 $\mu \mathrm{m}$ particles are the most common sizes of fish DNA molecules obtained from water [55-57]. Thus, selecting a corresponding range of pore sizes may ensure the success of fish eDNA capture. The eDNA of water samples can be effectively collected with cellulose acetate (CA), cellulose nitrate $(\mathrm{CN})$, mixed cellulose acetate and nitrate (MCE), mixed cellulose nitrate (MCN), glass fiber (GF), polycarbonate (PC), polycarbonate track-etched (PCTE), polyethersulfone (PES), and nylon filters (Table S2). The percentage of filter materials used in fish eDNA collection is shown in Figure 1b. GF filers are most common and are used in $50 \%$ of cases, followed by CN filters ( $14 \%$ ). Although Kumar et al. [32] concluded that cellulose-based filters consistently performed better than other filters based on the results of eDNA studies for aquatic organisms, there is some controversy regarding whether cellulose-based filters or GF filters are the most suitable filter types for fish DNA capture. In experimental aquariums, Renshaw et al. [58] and Hinlo et al. [52] found that using CN filters yielded higher eDNA copies than using other filters for bluegill sunfish Lepomis macrochirus and oriental 
weather loach Misgurnus anguillicaudatus, respectively. In a field survey, Sepulveda et al. [59] found that a $1.0 \mu \mathrm{m}$ MCE filter resulted in higher detection rates than a $1.2 \mu \mathrm{m}$ GF filter for northern pike Esox lucius in lakes. However, in experimental aquariums, Eichmiller et al. [48] and Minamoto et al. [60] recommended that GF filters are optimal for collecting eDNA from common carp Cyprinus carpio. Lacoursiere-Roussel et al. [61] reported that GF filters performed better than MCE filters for brook charr Salvelinus fontinalis detection. Because of the different water bodies and target species in these studies, a general criterion cannot be drawn for future reference. Although it is recommended to conduct a pre-experiment to determine a suitable capture method before performing a formal survey, it is also important to give a general choice in advance. Here, we recommend using GF filters for fish eDNA capture, as they have been commonly used in diverse water samples from aquarium water, lentic systems, or lotic systems for fish detection (Figure 1c). Additionally, $0.7 \mu \mathrm{m}$ is a general pore size of GF filters used for water filtration (Figure 1a); however, when filtering turbid water samples, a larger pore size $(>1 \mu \mathrm{m})$ should be considered to avoid filter logging. If researchers wish to simultaneously use more than one type of filter, capsule filters may be required which can also contain two filter membranes of different pore sizes and materials [62].

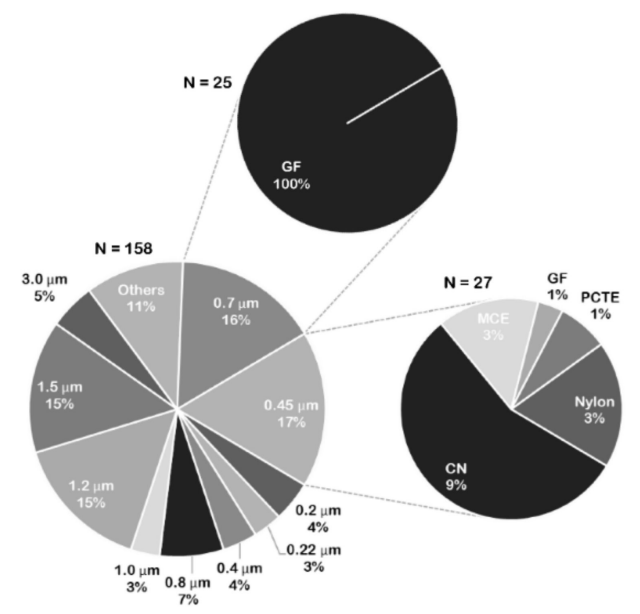

(a)

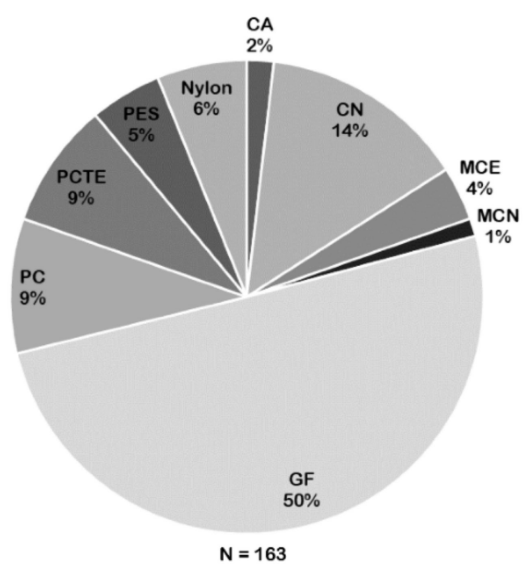

(b)

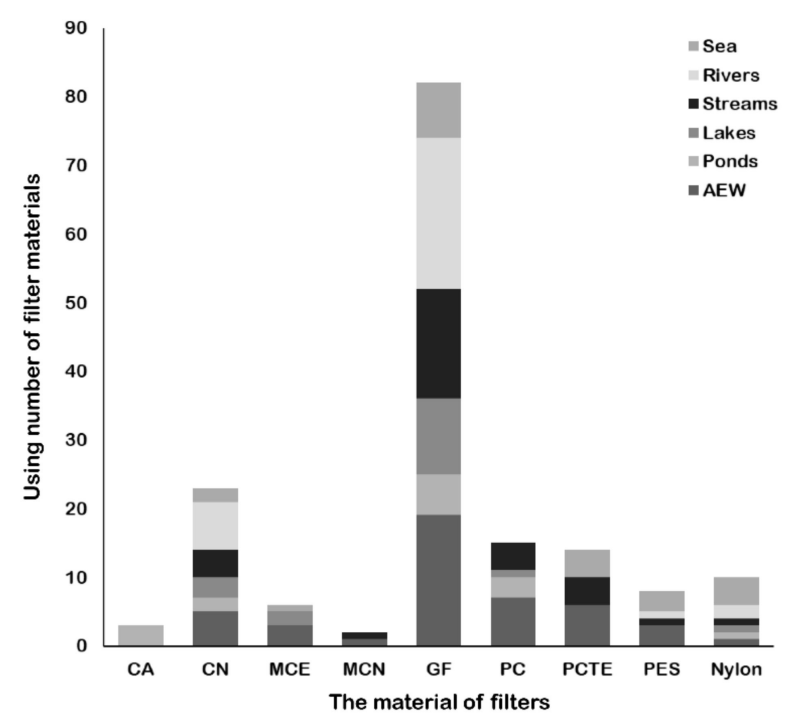

(c)

Figure 1. Various pore sizes and materials for filter types used for fish eDNA capture. (a) Percentage of pore size and two main pore sizes corresponding material of filters used in water filtration. 
(b) Percentage of various material of filters used in water filtration. (c) Using number of various material of filters in diverse water samples from different water environments. Abscissa shows various material of filter types, and ordinate represents corresponding using number. Different studied water samples form water environment types are displayed as different shades. AEW refer to artificial or experimental water bodies. The filter material abbreviations are cellulose acetate (CA), cellulose nitrate (CN), mixed cellulose acetate and nitrate (MCE), mixed cellulose nitrate $(\mathrm{MCN})$, glass fiber (GF), polycarbonate (PC), polycarbonate track-etched (PCTE), and polyethersulfone (PES).

\section{4. eDNA Extraction Methods}

For fish eDNA detection, in addition to the few studies that used cetyl trimethylammonium bromide (CTAB), phenol-chloroform-isoamyl alcohol (PCI), or salt DNA extraction methods, most studies have employed different commercial DNA extraction kits for eDNA extraction (Table S2, Figure 2). The most widely used eDNA extraction method is the DNeasy Blood and Tissue Kit (Qiagen, Hilden, Germany), followed by the PowerWater DNA Isolation Kit (MoBio, Hilden, Germany). Kumar et al. [32] and Tsuji et al. [24] compared the advantages and disadvantages of different methods for eDNA extraction. They found that the DNeasy Blood and Tissue Kit was optimal for eDNA extraction in most cases because it is non-toxic, simple, and less costly than other kits. The cost of PowerWater kit is higher than the DNeasy kit, but its PCR inhibitor removal can effectively improve PCR amplification and data quality [15,63]. Stoeckle et al. [64] systematically evaluated the influence of different environmental variables and inhibitors and found that the presence of sediment was the main factor responsible for lower eDNA detection in the water samples, regardless of whether flowing or still water was used. Determining such information beforehand can help decide whether a protocol involving inhibitor removal is required. Here, we recommend using the PowerWater DNA Isolation Kit for water samples containing humic substance, algae, or siliceous of sediment particles because of its PCR inhibitor removal step.

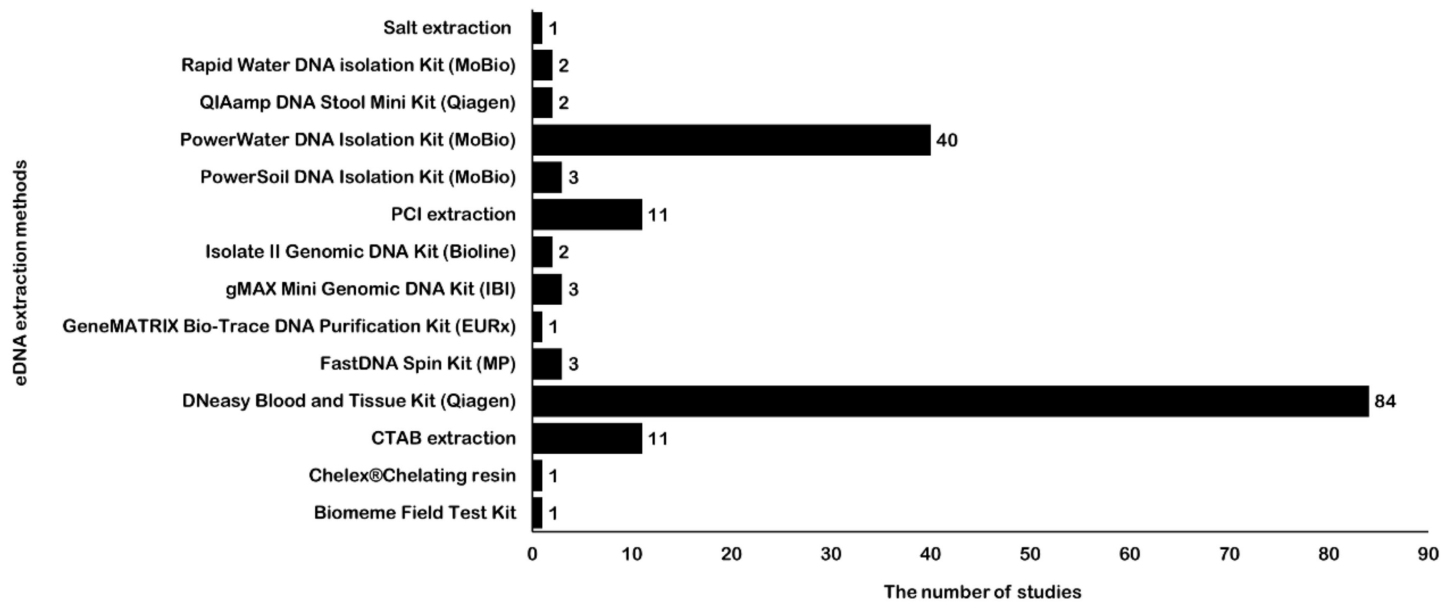

Figure 2. Application number of different eDNA extraction methods for fish detection. Abscissa shows the corresponding number of studies, and ordinate represents different eDNA extraction methods. The number of eDNA extraction methods is labeled following each bar. The abbreviations for extraction methods are cetyl trimethylammonium bromide (CTAB) and phenol-chloroform-isoamyl alcohol (PCI).

\section{Genetic Marker Selection}

Appropriate genetic markers and primers vary depending on the purpose of eDNA detection (Table S2). Specific primers are designed for single species detection, whereas generic primers are designed for diverse taxa assessment through metabarcoding. Mitochondrial and nuclear genes have already been utilized as genetic markers in eDNA assays; however, mitochondrial genes are considered as gold standard because they rapidly evolve and can better describe biodiversity; moreover, mitochondrial DNA has been shown to be reliable for evaluating degraded DNA, is informative for 
discriminating vertebrate species, and is adapted to survey fish diversity $[5,65]$. The commonly used markers for species-specific detection through fish eDNA are the cytochrome $b$ gene (Cytb; 70-150 bp), cytochrome oxidase subunit I gene (COI; 61-240 bp), and D-loop region (98-312 bp) (Table S3; Figure 3a). As $C y t b$ is the most popular genetic marker for characterizing eDNA from fish (Figure 3a), we suggest that investigators give priority to designing species-specific primers based on $C y t b$ for target species detection. In this review, 18 pairs of universal primers for fish eDNA metabarcoding were evaluated (Table S3). The $12 \mathrm{~S}$ rRNA markers have been utilized extensively in fish diversity assessments (Figure 3b). Based on the results of $12 S$ rRNA, the 12S-V5 [66], MiFish-U [29], and Teleo [30] primer sets are recommended for fish diversity analysis, as they provide the highest percentages of all $12 S$ rRNA markers used (15\%, 15\%, and 12\%, respectively; Figure 3b). Bylemans et al. [67] developed multiple software programs to evaluate the performance of 14 sets of universal primers in richness assessment of freshwater fish species from the Murray-Darling (Australia). The results showed that the MiFish-U, Teleo, and AcMDB07 primers were useful for fish eDNA metabarcoding surveys; however, the MiFish-U and AcMDB07 primers provided higher species detection probabilities compared to the Teleo primer set. Thus, before confirming the most suitable primer set, it is imperative to carefully estimate the history of local biodiversity and formulate the objectives for a metabarcoding survey. In addition, 16S rRNA is the second most popular genetic marker examined in fish diversity analysis. Here, combined use of the $12 \mathrm{~S}$ and $16 \mathrm{~S}$ markers is recommended to increase eDNA metabarcoding detection of target fish communities and reduce metabarcoding detection bias (see below).

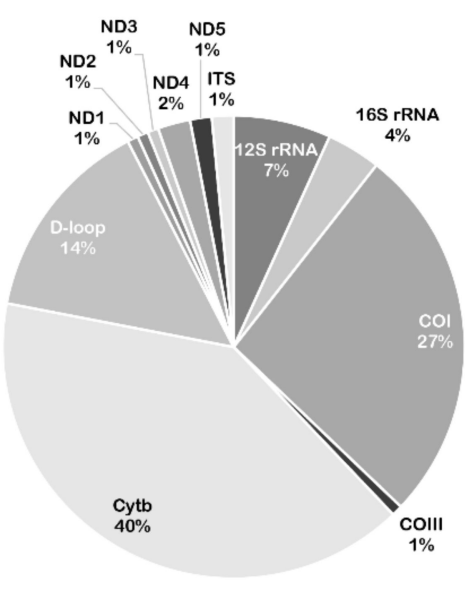

$N=132$

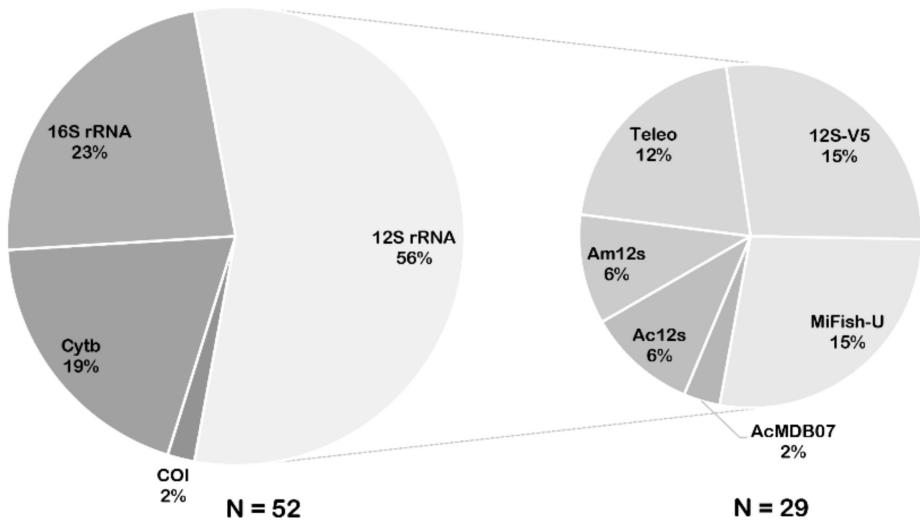

(b)

(a)

Figure 3. Percentages of genetic markers used for species-specific detection or eDNA metabarcoding. (a) Percentages of target genes used for species-specific polymerase chain reaction (PCR) assay. (b) Percentages of target genes and main marker corresponding primer sets used for metabarcoding analysis.

\section{4. eDNA Detection}

eDNA detection methods used in fish monitoring mainly include two types of species-specific detection and eDNA metabarcoding, which were described in detail in several reviews [1,5,19,24,32]. Most eDNA studies of fish monitoring have focused on species-specific detection including the detection of invasive and threatened species (Figure 4). Early detection of invasive species or evaluation of their eradication is essential for developing conservation strategies to protect the diversity of native species. Because of its sensitivity and cost-effectiveness, eDNA technology has recently become increasingly used as a management strategy for monitoring invasive fish before and after their eradication, such as Asian carps in the Great Lakes of the United States and Canada [25,40,41,68-70]. eDNA analysis can screen the presence or absence of rare fish species in water samples; thus, it has become very useful 
for monitoring and conserving vulnerable species. eDNA sampling has also become a common tool for surveying at-risk species because of its non-invasive nature and cost-effectiveness, such as for evaluating Green sturgeon [10,11] in the United States, Chinese sturgeon [71], and Mekong giant catfish [9] in Asia. In addition to the absence-presence detection of single species, estimating the species richness of fish communities is important for management and conservation. eDNA metabarcoding through HTS is a promising and powerful tool for fish diversity surveys.

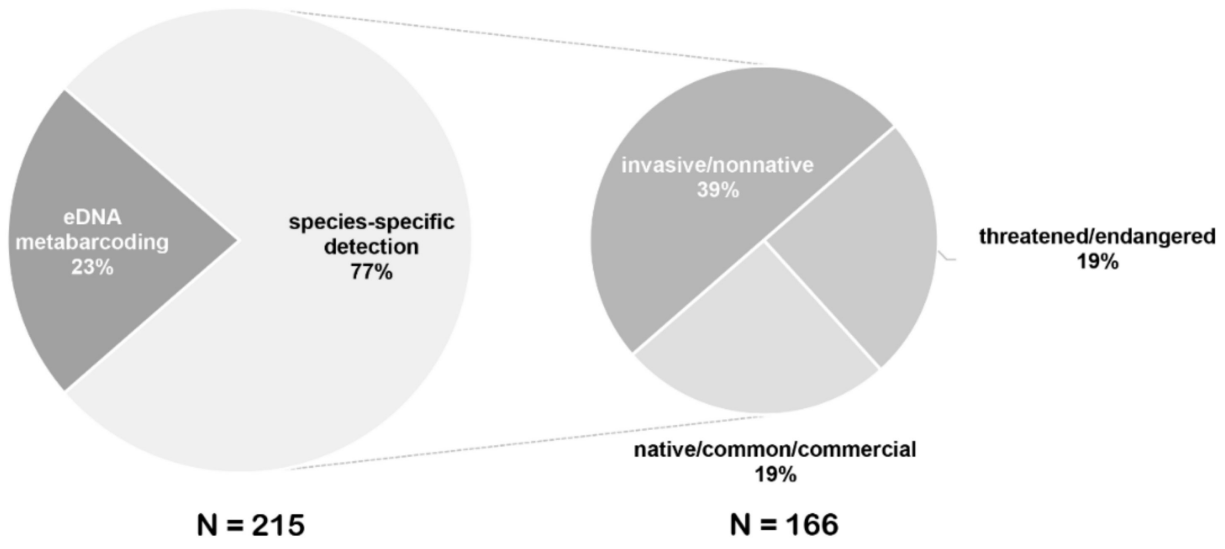

Figure 4. Percentages of eDNA studies employed for species-specific detection and eDNA metabarcoding. Percentages of different studied groups in species-specific detection are displayed in the smaller pie chart.

Initial eDNA detection employs cPCR with cloning or Sanger sequencing technologies to obtain target eDNA for species-specific detection [25,40,72,73]. Here, we recommend probe-based qPCR for target eDNA detection, which is preferred over CPCR in single-species detection because of its greater sensitivity and reliability [74-76]. Moreover, qPCR methods, which can quantify the target eDNA in samples, have been used to estimate fish abundance and biomass [77,78]. Methods involving ddPCR are also used in target species detection or quantification, as they are more sensitive at low eDNA concentrations. Doi et al. [28,79] found that ddPCR was more effective than qPCR for eDNA detection or quantification of rare invasive species, such as bluegill sunfish and common carp. However, the assay costs of ddPCR are higher than those of qPCR [80]. Thus, before cost reduction of the ddPCR assay, we do not recommend performing ddPCR for single-species detection.

In addition to the lab-based eDNA approaches described above, a portable field-based eDNA platform with a field-based DNA extraction kit, shelf-stable assay, and portable real-time PCR thermocycler have been recently employed in a species-specific eDNA survey. Sepulveda et al. [59] compared the performance of a portable field-based eDNA platform to lab-based eDNA approaches for detecting invasive northern pike in eight lakes on Alaska's Kenai Peninsula. The portable, field-based platform is less time-consuming $(\sim 1 \mathrm{~h})$ than lab-based approaches from water collection to final results, but is less sensitive than lab-based approaches and more prone to inhibition, thus increasing the potential of obtaining false-negative results. Until these sensitivity and inhibition issues can be resolved, this portable field-based approach is not recommended as a substitute for lab-based eDNA approaches.

HTS can be advantageous when targeting multiple species via eDNA metabarcoding, making it possible to eliminate the costly and time-consuming steps of cloning and sequencing of single PCR products by Sanger sequencing [3]. A detailed comparison of many sequencing platforms and approaches used for eDNA metabarcoding analysis was conducted by Lear et al. [31]. The authors concluded that the low cost per sequence makes Illumina platforms suitable for high-throughput analysis of eDNA metabarcoding, allowing for high throughput and large coverage. Lear et al. [31] also mentioned that the emerging portable sequencing technology allowing real-time sequencing in 
the field has great potential for eDNA research; however, its error rates must be further improved. Furthermore, Deiner et al. [81] amplified and sequenced longer fragments separately from fish eDNA from a mesocosm and natural stream and successfully recovered the mitogenomes of several species from fish eDNA in vitro, in situ, and in the field, indicating that not all eDNA is degraded. In the future, sequencing of mitochondrial genomes from eDNA samples may overcome the low resolution and species identification observed with short-fragment PCR amplicon-based methods.

\section{Detection Errors}

eDNA technology remains challenging when detecting errors such as false-positives and false-negatives. False-positives refer to the apparent detection of a species despite its absence in the environment, whereas false-negatives in eDNA analysis refer to the failure to detect the DNA of a species despite its presence in the environment [82,83]. Either false-positives or false-negatives make eDNA results uncertain in terms of the absence or presence of a species. Methodological errors and environmental factors are the two major factors that can cause false detections. Understanding the origin, state, transport, and fate of eDNA in aquatic ecosystems [6,84,85] can help explain uncertainties in eDNA detection; additionally, standards and guidelines must also be developed to ensure the adequacy of quality assurance, as was performed in ancient DNA research [86]. Furlan et al. [87,88] developed a framework for reducing or eliminating potential false-positive or false-negative detection during eDNA analysis. Thomsen et al. [1] and Cristescu et al. [89] also provide detailed recommendations for field sampling designs and lab practices to reduce or avoid false detections in eDNA studies. Detailed solutions to these issues can be found in the literature cited above. Here, we highlight some key standards in field sampling and laboratory levels to eliminate methodological errors.

\subsection{Contamination Control}

Exogenous or non-target contaminating DNA is ubiquitous during eDNA processing, which is the dominant factor causing false-positives [90]. Based on the strict decontamination protocols of ancient DNA research [6,91], spatial separation and surface cleaning are effective methods for avoiding sample, lab, or cross-contamination. Thus, we recommend that eDNA analysis should be done in separated laboratories (i.e. sample preparation room, DNA extraction room and amplification/sequencing room) which are used in a one-way system by qualified researchers only. Researchers should wear suitable lab clothes for trace labs. All equipment must be bleached with $10 \%$ bleach solution or treated with $254 \mathrm{~nm}$ ultraviolet light prior to sampling, filtering, and pre-PCR steps. When filtering water samples, the contact surface of the filters for each sample should also be treated with $10 \%$ bleach and rinsed with double-distilled $\mathrm{H}_{2} \mathrm{O}$ before new sample filtration $[48,58]$ to prevent cross-contamination between samples. Furthermore, strictly setting up multiple negative controls (such as double-distilled $\mathrm{H}_{2} \mathrm{O}$ for blank sample) including a field blank, filtration blank, extraction blank, and PCR blank [47,92], is necessary for evaluating contamination during the entire eDNA process. In addition, considering the repeatability of eDNA results, analysis of at least some samples should be independently repeated in another laboratory as described for ancient DNA research [6,91].

\subsection{Reducing Primer Bias}

Primer bias occurs in PCR amplification of eDNA templates during metabarcoding, such as mismatch between primers and templates or unequal amplification efficiency, resulting in false-negative detection of the target taxon or low-abundance species [15]. PCR replicates or the use of multiple genetic markers in PCR amplification increases the chance of amplifying low levels of eDNA from rare species or overcome a shortage of single genetic markers, which can improve target detection and reduce primer bias $[83,93]$. We recommend performing triplicate PCRs for each sample and pooling the samples to minimize bias in individual PCRs $[38,94]$. To increase eDNA metabarcoding detection 
of target fish communities, we recommend using both the $12 \mathrm{~S}$ and $16 \mathrm{~S}$ markers (Table S3), which is a common solution employed to eliminate PCR amplification bias in previous studies [95-98].

\section{Conclusions}

Although species detection using eDNA has many advantages, this method cannot fully substitute classical monitoring, particularly if information on population demography is needed for conservation management (for advantages and disadvantages, see Stoeckle et al. [99]). Despite its technical challenges, eDNA remains a promising and powerful tool for fish monitoring and conservation. In the last decade, eDNA methods have been increasingly utilized in fish detection for monitoring and conserving fish diversity. Numerous standards have been published in international journals; however, few investigators follow these standards in the field. Various protocols for eDNA methods prevent beginners from efficiently performing eDNA research, and published results are difficult with respect to their reliability. Here, we supplement and emphasize important standards of eDNA technology, particularly water collection, eDNA capture and extraction, genetic marker selection, and eDNA detection in fish surveys. We also highlighted key standards for reducing or avoiding false and negative detection in eDNA studies. Overall, our literature survey suggests that in most cases of fish detection, 1 or $2 \mathrm{~L}$ surface water collection, and eDNA capture on $0.7 \mu \mathrm{m}$ GF filters, followed by extraction with the DNeasy Blood and Tissue Kit or PowerWater DNA Isolation Kit can be performed to obtain high-quality eDNA and reliable results. Subsequently, using specific primers based on Cytb for species-specific qPCR assay or using universal primers based on both $12 S$ rRNA and $16 S$ rRNA for eDNA metabarcoding via HTS is effective for target species identification or species richness assessment. We can also establish quality controls to minimize detection errors by mitigating contamination including spatial separation, surface cleaning, and negative control in each step of eDNA analysis, performing PCR replication such as triplicate PCRs for each sample, and using both $12 S$ and $16 \mathrm{~S}$ markers in multiple primer sets. Decontamination and negative control are aimed at decreasing false-positives, whereas PCR replication and using multiple genetic markers are aimed at decreasing false-negatives. Nevertheless, these standards must be adapted occasionally considering technical progress. The emergence of the portable field-based eDNA platform and portable sequencing technology suggest that with additional development and improvements, eDNA techniques can be used successfully to rapidly evaluate environmental samples.

Supplementary Materials: The following are available online at http://www.mdpi.com/2073-4425/11/3/296/s1: Table S1: Fish eDNA studies from 2011 to 2019 reviewed in this paper; Table S2: Summary of sampling volume and depth, eDNA extraction, genetic markers, amplification and sequencing used to detect fish eDNA in water bodies; Table S3: 18 pairs of universal primers used in eDNA metabarcoding for fish diversity assessments.

Author Contributions: Conceptualization, Z.P. and A.L.; investigation and synthesis, L.S.; writing-original draft preparation, L.S.; writing-review and editing, Z.P. and A.L.; visualization, L.S.; supervision, Z.P.; funding acquisition, Z.P. All authors have read and agreed to the published version of the manuscript.

Funding: This research was funded by the National Key Research and Development Program of China (No. 2018YFD0900805) and the National Natural Science Foundation of China (No. 31872204).

Acknowledgments: We thank members from Peng's lab for constructive discussion.

Conflicts of Interest: The authors declare no conflict of interest.

\section{References}

1. Thomsen, P.F.; Willerslev, E. Environmental DNA-An emerging tool in conservation for monitoring past and present biodiversity. Biol. Conserv. 2015, 183, 4-18. [CrossRef]

2. Coble, A.A.; Flinders, C.A.; Homyack, J.A.; Penaluna, B.E.; Cronn, R.C.; Weitemier, K. eDNA as a tool for identifying freshwater species in sustainable forestry: A critical review and potential future applications. Sci. Total Environ. 2019, 649, 1157-1170. [CrossRef] [PubMed]

3. Taberlet, P.; Coissac, E.; Hajibabaei, M.; Rieseberg, L.H. Environmental DNA. Mol. Ecol. 2012, 21, $1789-1793$. [CrossRef] [PubMed] 
4. Bohmann, K.; Evans, A.; Gilbert, M.T.; Carvalho, G.R.; Creer, S.; Knapp, M.; Yu, D.W.; de Bruyn, M. Environmental DNA for wildlife biology and biodiversity monitoring. Trends Ecol. Evol. 2014, 29, 358-367. [CrossRef] [PubMed]

5. Rees, H.C.; Maddison, B.C.; Middleditch, D.J.; Patmore, J.R.M.; Gough, K.C.; Crispo, E. The detection of aquatic animal species using environmental DNA - a review of eDNA as a survey tool in ecology. J. Appl. Ecol. 2014, 51, 1450-1459. [CrossRef]

6. Pedersen, M.W.; Overballe-Petersen, S.; Ermini, L.; Sarkissian, C.D.; Haile, J.; Hellstrom, M.; Spens, J.; Thomsen, P.F.; Bohmann, K.; Cappellini, E.; et al. Ancient and modern environmental DNA. Phil. Trans. R. Soc. B 2015, 370, 20130383. [CrossRef]

7. Deiner, K.; Fronhofer, E.A.; Machler, E.; Walser, J.C.; Altermatt, F. Environmental DNA reveals that rivers are conveyer belts of biodiversity information. Nat. Commun. 2016, 7, 12544. [CrossRef]

8. Hansen, B.K.; Bekkevold, D.; Clausen, L.W.; Nielsen, E.E. The sceptical optimist: Challenges and perspectives for the application of environmental DNA in marine fisheries. Fish Fish. 2018, 19, 751-768. [CrossRef]

9. Eva, B.; Harmony, P.; Thomas, G.; Francois, G.; Alice, V.; Claude, M.; Tony, D. Trails of river monsters: Detecting critically endangered Mekong Giant Catfish Pangasianodon gigas using environmental DNA. Glob. Ecol. Conserv. 2016, 7, 148-156. [CrossRef]

10. Bergman, P.S.; Schumer, G.; Blankenship, S.; Campbell, E. Detection of adult Green Sturgeon using environmental DNA analysis. PLoS ONE 2016, 11, e0153500. [CrossRef]

11. Anderson, J.T.; Schumer, G.; Anders, P.J.; Horvath, K.; Merz, J.E. Confirmed observation: A north American Green Sturgeon Acipenser. medirostris. recorded in the Stanislaus river, California. J. Fish Wildl. Manag. 2018, 9, 624-630. [CrossRef]

12. Blanchet, S. The use of molecular tools in invasion biology: An emphasis on freshwater ecosystems. Fish. Manag. Ecol. 2012, 19, 120-132. [CrossRef]

13. Lodge, D.M. Conservation in a cup of water: Estimating biodiversity and population abundance from environmental DNA. Mol. Ecol. 2012, 21, 2555-2558. [CrossRef] [PubMed]

14. Goldberg, C.S.; Strickler, K.M.; Pilliod, D.S. Moving environmental DNA methods from concept to practice for monitoring aquatic macroorganisms. Biol. Conserv. 2015, 183, 1-3. [CrossRef]

15. Goldberg, C.S.; Turner, C.R.; Deiner, K.; Klymus, K.E.; Thomsen, P.F.; Murphy, M.A.; Spear, S.F.; McKee, A.; Oyler-McCance, S.J.; Cornman, R.S.; et al. Critical considerations for the application of environmental DNA methods to detect aquatic species. Methods Ecol. Evol. 2016, 7, 1299-1307. [CrossRef]

16. Hoffmann, C.; Schubert, G.; Calvignac-Spencer, S. Aquatic biodiversity assessment for the lazy. Mol. Ecol. 2016, 25, 846-848. [CrossRef]

17. Keck, F.; Vasselon, V.; Tapolczai, K.; Rimet, F.; Bouchez, A. Freshwater biomonitoring in the information age. Front. Ecol. Environ. 2017, 15, 266-274. [CrossRef]

18. Trebitz, A.S.; Hoffman, J.C.; Darling, J.A.; Pilgrim, E.M.; Kelly, J.R.; Brown, E.A.; Chadderton, W.L.; Egan, S.P.; Grey, E.K.; Hashsham, S.A.; et al. Early detection monitoring for aquatic non-indigenous species: Optimizing surveillance, incorporating advanced technologies, and identifying research needs. J. Environ. Manag. 2017, 202, 299-310. [CrossRef]

19. Evans, N.T.; Lamberti, G.A. Freshwater fisheries assessment using environmental DNA: A primer on the method, its potential, and shortcomings as a conservation tool. Fish. Res. 2018, 197, 60-66. [CrossRef]

20. Harper, L.R.; Buxton, A.S.; Rees, H.C.; Bruce, K.; Brys, R.; Halfmaerten, D.; Read, D.S.; Watson, H.V.; Sayer, C.D.; Jones, E.P.; et al. Prospects and challenges of environmental DNA (eDNA) monitoring in freshwater ponds. Hydrobiologia 2018, 826, 25-41. [CrossRef]

21. Pawlowski, J.; Kelly-Quinn, M.; Altermatt, F.; Apotheloz-Perret-Gentil, L.; Beja, P.; Boggero, A.; Borja, A.; Bouchez, A.; Cordier, T.; Domaizon, I.; et al. The future of biotic indices in the ecogenomic era: Integrating (e) DNA metabarcoding in biological assessment of aquatic ecosystems. Sci. Total Environ. 2018, 637, 1295-1310. [CrossRef] [PubMed]

22. Adams, C.I.M.; Knapp, M.; Gemmell, N.J.; Jeunen, G.J.; Bunce, M.; Lamare, M.D.; Taylor, H.R. Beyond biodiversity: Can environmental DNA (eDNA) cut it as a population genetics tool? Genes 2019, 10, 192. [CrossRef] [PubMed]

23. Radinger, J.; Britton, J.R.; Carlson, S.M.; Magurran, A.E.; Alcaraz-Hernandez, J.D.; Almodovar, A.; Benejam, L.; Fernandez-Delgado, C.; Nicola, G.G.; Oliva-Paterna, F.J.; et al. Effective monitoring of freshwater fish. Fish Fish. 2019, 20, 729-747. [CrossRef] 
24. Tsuji, S.; Takahara, T.; Doi, H.; Shibata, N.; Yamanaka, H. The detection of aquatic macroorganisms using environmental DNA analysis-A review of methods for collection, extraction, and detection. Environ. DNA 2019, 1, 99-108. [CrossRef]

25. Jerde, C.L.; Mahon, A.R.; Chadderton, W.L.; Lodge, D.M. “Sight-unseen” detection of rare aquatic species using environmental DNA. Conserv. Lett. 2011, 4, 150-157. [CrossRef]

26. Thomsen, P.F.; Kielgast, J.; Iversen, L.L.; Moller, P.R.; Rasmussen, M.; Willerslev, E. Detection of a diverse marine fish fauna using environmental DNA from seawater samples. PLoS ONE 2012, 7, e41732. [CrossRef]

27. Minamoto, T.; Yamanaka, H.; Takahara, T.; Honjo, M.N.; Kawabata, Z.I. Surveillance of fish species composition using environmental DNA. Limnology 2011, 13, 193-197. [CrossRef]

28. Doi, H.; Takahara, T.; Minamoto, T.; Matsuhashi, S.; Uchii, K.; Yamanaka, H. Droplet digital polymerase chain reaction (PCR) outperforms real-time PCR in the detection of environmental DNA from an invasive fish species. Environ. Sci. Technol. 2015, 49, 5601-5608. [CrossRef]

29. Miya, M.; Sato, Y.; Fukunaga, T.; Sado, T.; Poulsen, J.Y.; Sato, K.; Minamoto, T.; Yamamoto, S.; Yamanaka, H.; Araki, H.; et al. Mifish, a set of universal PCR primers for metabarcoding environmental DNA from fishes: Detection of more than 230 subtropical marine species. R. Soc. Open Sci. 2015, 2, 150088. [CrossRef]

30. Valentini, A.; Taberlet, P.; Miaud, C.; Civade, R.; Herder, J.; Thomsen, P.F.; Bellemain, E.; Besnard, A.; Coissac, E.; Boyer, F.; et al. Next-generation monitoring of aquatic biodiversity using environmental DNA metabarcoding. Mol. Ecol. 2016, 25, 929-942. [CrossRef]

31. Lear, G.; Dickie, I.; Banks, J.; Boyer, S.; Buckley, H.L.; Buckley, T.R.; Cruickshank, R.; Dopheide, A.; Handley, K.M.; Hermans, S.; et al. Methods for the extraction, storage, amplification and sequencing of DNA from environmental samples. N. Z. J. Ecol. 2018, 42, 10-50A. [CrossRef]

32. Kumar, G.; Eble, J.E.; Gaither, M.R. A practical guide to sample preservation and pre-PCR processing of aquatic environmental DNA. Mol. Ecol. Resour. 2019, 20, 29-39. [CrossRef] [PubMed]

33. Belle, C.C.; Stoeckle, B.C.; Geist, J. Taxonomic and geographical representation of freshwater environmental DNA research in aquatic conservation. Aquat. Conserv. 2019, 29, 1996-2009. [CrossRef]

34. Doi, H.; Uchii, K.; Matsuhashi, S.; Takahara, T.; Yamanaka, H.; Minamoto, T. Isopropanol precipitation method for collecting fish environmental DNA. Limnol. Oceanogr.-Methods 2017, 15, 212-218. [CrossRef]

35. Civade, R.; Dejean, T.; Valentini, A.; Roset, N.; Raymond, J.-C.; Bonin, A.; Taberlet, P.; Pont, D. Spatial representativeness of environmental DNA metabarcoding signal for fish biodiversity assessment in a natural freshwater system. PLoS ONE 2016, 11, e0157366. [CrossRef]

36. Strickland, G.J.; Roberts, J.H. Utility of eDNA and occupancy models for monitoring an endangered fish across diverse riverine habitats. Hydrobiologia 2019, 826, 129-144. [CrossRef]

37. Klobucar, S.L.; Rodgers, T.W.; Budy, P. At the forefront: Evidence of the applicability of using environmental DNA to quantify the abundance of fish populations in natural lentic waters with additional sampling considerations. Can. J. Fish. Aquat. Sci. 2017, 74, 2030-2034. [CrossRef]

38. Hanfling, B.; Handley, L.L.; Read, D.S.; Hahn, C.; Li, J.; Nichols, P.; Blackman, R.C.; Oliver, A.; Winfield, I.J. Environmental DNA metabarcoding of lake fish communities reflects long-term data from established survey methods. Mol. Ecol. 2016, 25, 3101-3119. [CrossRef]

39. Yamamoto, S.; Masuda, R.; Sato, Y.; Sado, T.; Araki, H.; Kondoh, M.; Minamoto, T.; Miya, M. Environmental DNA metabarcoding reveals local fish communities in a species-rich coastal sea. Sci. Rep. 2017, 7, 40368. [CrossRef]

40. Jerde, C.L.; Chadderton, W.L.; Mahon, A.R.; Renshaw, M.A.; Corush, J.; Budny, M.L.; Mysorekar, S.; Lodge, D.M. Detection of Asian carp DNA as part of a great lakes basin-wide surveillance program. Can. J. Fish. Aquat. Sci. 2013, 70, 522-526. [CrossRef]

41. Wilson, C.; Wright, E.; Bronnenhuber, J.; MacDonald, F.; Belore, M.; Locke, B. Tracking ghosts: Combined electrofishing and environmental DNA surveillance efforts for Asian carps in Ontario waters of Lake Erie. Manag. Biol. Invasion 2014, 5, 225-231. [CrossRef]

42. Keskin, E.; Unal, E.M.; Atar, H.H. Detection of rare and invasive freshwater fish species using eDNA pyrosequencing: Lake iznik ichthyofauna revised. Biochem. Syst. Ecol. 2016, 67, 29-36. [CrossRef]

43. Uchii, K.; Doi, H.; Yamanaka, H.; Minamoto, T. Distinct seasonal migration patterns of Japanese native and non-native genotypes of common carp estimated by environmental DNA. Ecol. Evol. 2017, 7, 8515-8522. [CrossRef] [PubMed] 
44. Davison, P.I.; Copp, G.H.; Creach, V.; Vilizzi, L.; Britton, J.R. Application of environmental DNA analysis to inform invasive fish eradication operations. Sci. Nat. 2017, 104, 35. [CrossRef]

45. Hinlo, R.; Lintermans, M.; Gleeson, D.; Broadhurst, B.; Furlan, E. Performance of eDNA assays to detect and quantify an elusive benthic fish in upland streams. Biol. Invasions 2018, 20, 3079-3093. [CrossRef]

46. Sato, H.; Sogo, Y.; Doi, H.; Yamanaka, H. Usefulness and limitations of sample pooling for environmental DNA metabarcoding of freshwater fish communities. Sci. Rep. 2017, 7, 14860. [CrossRef]

47. Zhang, S.; Lu, Q.; Wang, Y.Y.; Wang, X.M.; Zhao, J.D.; Yao, M. Assessment of fish communities using environmental DNA: Effect of spatial sampling design in lentic systems of different sizes. Mol. Ecol. Resour. 2020, 20, 242-255. [CrossRef]

48. Eichmiller, J.J.; Miller, L.M.; Sorensen, P.W. Optimizing techniques to capture and extract environmental DNA for detection and quantification of fish. Mol. Ecol. Resour. 2016, 16, 56-68. [CrossRef]

49. Sutter, M.; Kinziger, A.P. Rangewide tidewater goby occupancy survey using environmental DNA. Conserv. Genet. 2019, 20, 597-613. [CrossRef]

50. Fukaya, K.; Murakami, H.; Yoon, S.; Minami, K.; Osada, Y.; Yamamoto, S.; Masuda, R.; Kasai, A.; Miyashita, K.; Minamoto, T.; et al. Estimating fish population abundance by integrating quantitative data on environmental DNA and hydrodynamic modelling. bioRxiv. 2018, 482489. [CrossRef]

51. Ghosal, R.; Eichmiller, J.J.; Witthuhn, B.A.; Sorensen, P.W. Attracting common carp to a bait site with food reveals strong positive relationships between fish density, feeding activity, environmental DNA, and sex pheromone release that could be used in invasive fish management. Ecol. Evol. 2018, 8, 6714-6727. [CrossRef] [PubMed]

52. Hinlo, R.; Gleeson, D.; Lintermans, M.; Furlan, E. Methods to maximise recovery of environmental DNA from water samples. PLoS ONE 2017, 12, e0179251. [CrossRef] [PubMed]

53. Schultz, M.T.; Lance, R.F. Modeling the sensitivity of field surveys for detection of environmental DNA (eDNA). PLoS ONE 2015, 10, e0141503. [CrossRef]

54. Sigsgaard, E.E.; Nielsen, I.B.; Bach, S.S.; Lorenzen, E.D.; Robinson, D.P.; Knudsen, S.W.; Pedersen, M.W.; Jaidah, M.A.; Orlando, L.; Willerslev, E.; et al. Population characteristics of a large whale shark aggregation inferred from seawater environmental DNA. Nat. Ecol. Evol. 2016, 1, 4. [CrossRef] [PubMed]

55. Turner, C.R.; Barnes, M.A.; Xu, C.C.Y.; Jones, S.E.; Jerde, C.L.; Lodge, D.M.; Gilbert, M. Particle size distribution and optimal capture of aqueous macrobial eDNA. Methods Ecol. Evol. 2014, 5, 676-684. [CrossRef]

56. Wilcox, T.M.; McKelvey, K.S.; Young, M.K.; Lowe, W.H.; Schwartz, M.K. Environmental DNA particle size distribution from Brook Trout (Salvelinus fontinalis). Conserv. Genet. Resour. 2015, 7, 639-641. [CrossRef]

57. Sassoubre, L.M.; Yamahara, K.M.; Gardner, L.D.; Block, B.A.; Boehm, A.B. Quantification of environmental DNA (eDNA) shedding and decay rates for three marine fish. Environ. Sci. Technol. 2016, 50, 10456-10464. [CrossRef]

58. Renshaw, M.A.; Olds, B.P.; Jerde, C.L.; McVeigh, M.M.; Lodge, D.M. The room temperature preservation of filtered environmental DNA samples and assimilation into a phenol-chloroform-isoamyl alcohol DNA extraction. Mol. Ecol. Resour. 2015, 15, 168-176. [CrossRef]

59. Sepulveda, A.J.; Hutchins, P.R.; Massengill, R.L.; Dunker, K.J. Tradeoffs of a portable, field-based environmental DNA platform for detecting invasive northern pike (Esox lucius) in Alaska. Manag. Biol. Invasion 2018, 9, 253-258. [CrossRef]

60. Minamoto, T.; Naka, T.; Moji, K.; Maruyama, A. Techniques for the practical collection of environmental DNA: Filter selection, preservation, and extraction. Limnology 2016, 17, 23-32. [CrossRef]

61. Lacoursiere-Roussel, A.; Rosabal, M.; Bernatchez, L. Estimating fish abundance and biomass from eDNA concentrations: Variability among capture methods and environmental conditions. Mol. Ecol. Resour. 2016, 16, 1401-1414. [CrossRef] [PubMed]

62. Spens, J.; Evans, A.R.; Halfmaerten, D.; Knudsen, S.W.; Sengupta, M.E.; Mak, S.S.T.; Sigsgaard, E.E.; Hellström, M.; Yu, D. Comparison of capture and storage methods for aqueous macrobial eDNA using an optimized extraction protocol: Advantage of enclosed filter. Methods Ecol. Evol. 2017, 8, 635-645. [CrossRef]

63. Kelly, R.P.; Shelton, A.O.; Gallego, R. Understanding PCR processes to draw meaningful conclusions from environmental DNA studies. Sci. Rep. 2019, 9, 12133. [CrossRef] 
64. Stoeckle, B.C.; Beggel, S.; Cerwenka, A.F.; Motivans, E.; Kuehn, R.; Geist, J. A systematic approach to evaluate the influence of environmental conditions on eDNA detection success in aquatic ecosystems. PLoS ONE 2017, 12, e0189119. [CrossRef] [PubMed]

65. Freeland, J.R. The importance of molecular markers and primer design when characterizing biodiversity from environmental DNA. Genome 2017, 60, 358-374. [CrossRef]

66. Kelly, R.P.; Port, J.A.; Yamahara, K.M.; Crowder, L.B. Using environmental DNA to census marine fishes in a large mesocosm. PLoS ONE 2014, 9, e86175. [CrossRef]

67. Bylemans, J.; Gleeson, D.M.; Hardy, C.M.; Furlan, E. Toward an ecoregion scale evaluation of eDNA metabarcoding primers: A case study for the freshwater fish biodiversity of the Murray-Darling Basin (Australia). Ecol. Evol. 2018, 8, 8697-8712. [CrossRef]

68. Wittmann, M.E.; Jerde, C.L.; Howeth, J.G.; Maher, S.P.; Deines, A.M.; Jenkins, J.A.; Whitledge, G.W.; Burbank, S.R.; Chadderton, W.L.; Mahon, A.R.; et al. Grass carp in the great lakes region: Establishment potential, expert perceptions, and re-evaluation of experimental evidence of ecological impact. Can. J. Fish. Aquat. Sci. 2014, 71, 992-999. [CrossRef]

69. Erickson, R.A.; Rees, C.B.; Coulter, A.A.; Merkes, C.M.; McCalla, S.G.; Touzinsky, K.F.; Walleser, L.; Goforth, R.R.; Amberg, J.J. Detecting the movement and spawning activity of bigheaded carps with environmental DNA. Mol. Ecol. Resour. 2016, 16, 957-965. [CrossRef]

70. Wozney, K.M.; Wilson, C.C. Quantitative PCR multiplexes for simultaneous multispecies detection of Asian carp eDNA. J. Great Lakes Res. 2017, 43, 771-776. [CrossRef]

71. Xu, N.; Zhu, B.; Shi, F.; Shao, K.; Que, Y.; Li, W.; Li, W.; Jiao, W.; Tian, H.; Xu, D.; et al. Monitoring seasonal distribution of an endangered anadromous sturgeon in a large river using environmental DNA. Sci. Nat. 2018, 105, 62. [CrossRef] [PubMed]

72. Dejean, T.; Valentini, A.; Duparc, A.; Pellier-Cuit, S.; Pompanon, F.; Taberlet, P.; Miaud, C. Persistence of environmental DNA in freshwater ecosystems. PLoS ONE 2011, 6, e23398. [CrossRef]

73. Keskin, E. Detection of invasive freshwater fish species using environmental DNA survey. Biochem. Syst. Ecol. 2014, 56, 68-74. [CrossRef]

74. Amberg, J.J.; McCalla, S.G.; Monroe, E.; Lance, R.; Baerwaldt, K.; Gaikowski, M.P. Improving efficiency and reliability of environmental DNA analysis for Silver Carp. J. Great Lakes Res. 2015, 41,367-373. [CrossRef]

75. Robinson, C.; Garcia de Leaniz, C.; Rolla, M.; Consuegra, S. Monitoring the eradication of the highly invasive Topmouth Gudgeon (Pseudorasbora parva) using a novel eDNA assay. Environ. DNA 2019, 1, 74-85. [CrossRef]

76. Wilcox, T.M.; McKelvey, K.S.; Young, M.K.; Jane, S.F.; Lowe, W.H.; Whiteley, A.R.; Schwartz, M.K. Robust detection of rare species using environmental DNA: The importance of primer specificity. PLoS ONE 2013, 8, e59520. [CrossRef]

77. Mizumoto, H.; Urabe, H.; Kanbe, T.; Fukushima, M.; Araki, H. Establishing an environmental DNA method to detect and estimate the biomass of Sakhalin taimen; a critically endangered Asian salmonid. Limnology 2018, 19, 219-227. [CrossRef]

78. Baldigo, B.P.; Sporn, L.A.; George, S.D.; Ball, J.A. Efficacy of environmental DNA to detect and quantify brook trout populations in headwater streams of the Adirondack mountains, New York. Trans. Am. Fish. Soc. 2016, 146, 99-111. [CrossRef]

79. Doi, H.; Uchii, K.; Takahara, T.; Matsuhashi, S.; Yamanaka, H.; Minamoto, T. Use of droplet digital PCR for estimation of fish abundance and biomass in environmental DNA surveys. PLoS ONE 2015, 10, e0122763. [CrossRef]

80. Baker, M. Digital PCR hits its stride. Nat. Methods 2012, 9, 541-544. [CrossRef]

81. Deiner, K.; Renshaw, M.A.; Li, Y.Y.; Olds, B.P.; Lodge, D.M.; Pfrender, M.E. Long-range PCR allows sequencing of mitochondrial genomes from environmental DNA. Methods Ecol. Evol. 2017, 8, 1888-1898. [CrossRef]

82. Darling, J.A.; Mahon, A.R. From molecules to management: Adopting DNA-based methods for monitoring biological invasions in aquatic environments. Environ. Res. 2011, 111, 978-988. [CrossRef] [PubMed]

83. Ficetola, G.F.; Pansu, J.; Bonin, A.; Coissac, E.; Giguet-Covex, C.; De Barba, M.; Gielly, L.; Lopes, C.M.; Boyer, F.; Pompanon, F.; et al. Replication levels, false presences and the estimation of the presence/absence from eDNA metabarcoding data. Mol. Ecol. Resour. 2015, 15, 543-556. [CrossRef]

84. Barnes, M.A.; Turner, C.R.; Jerde, C.L.; Renshaw, M.A.; Chadderton, W.L.; Lodge, D.M. Environmental conditions influence eDNA persistence in aquatic systems. Environ. Sci. Technol. 2014, 48, 1819-1827. [CrossRef] [PubMed] 
85. Lacoursiere-Roussel, A.; Deiner, K. Environmental DNA is not the tool by itself. J. Fish Biol. 2019, 1-4. [CrossRef]

86. Hofreiter, M.; Paijmans, J.L.; Goodchild, H.; Speller, C.F.; Barlow, A.; Fortes, G.G.; Thomas, J.A.; Ludwig, A.; Collins, M.J. The future of ancient DNA: Technical advances and conceptual shifts. Bioessays 2015, 37, 284-293. [CrossRef]

87. Furlan, E.M.; Gleeson, D.; Hardy, C.M.; Duncan, R.P. A framework for estimating the sensitivity of eDNA surveys. Mol. Ecol. Resour. 2015, 16, 641-654. [CrossRef]

88. Furlan, E.M.; Gleeson, D. Improving reliability in environmental DNA detection surveys through enhanced quality control. Mar. Freshw. Res. 2017, 68, 388-395. [CrossRef]

89. Cristescu, M.E.; Hebert, P.D.N. Uses and misuses of environmental DNA in biodiversity science and conservation. Annu. Rev. Ecol. Evol. Syst. 2018, 49, 209-230. [CrossRef]

90. Champlot, S.; Berthelot, C.; Pruvost, M.; Bennett, E.A.; Grange, T.; Geigl, E.M. An efficient multistrategy DNA decontamination procedure of PCR reagents for hypersensitive PCR applications. PLoS ONE 2010, 5, e13042. [CrossRef]

91. Knapp, M.; Clarke, A.C.; Horsburgh, K.A.; Matisoo-Smith, E.A. Setting the stage-Building and working in an ancient DNA laboratory. Ann. Anat. 2012, 194, 3-6. [CrossRef] [PubMed]

92. Ushio, M.; Murakami, H.; Masuda, R.; Sado, T.; Miya, M.; Sakurai, S.; Yamanaka, H.; Minamoto, T.; Kondoh, M. Quantitative monitoring of multispecies fish environmental DNA using high-throughput sequencing. Metabarcoding Metagenom. 2018, 2, 1-15.

93. Evans, N.T.; Olds, B.P.; Renshaw, M.A.; Turner, C.R.; Li, Y.; Jerde, C.L.; Mahon, A.R.; Pfrender, M.E.; Lamberti, G.A.; Lodge, D.M. Quantification of mesocosm fish and amphibian species diversity via environmental DNA metabarcoding. Mol. Ecol. Resour. 2015, 16, 29-41. [CrossRef] [PubMed]

94. Minamoto, T.; Hayami, K.; Sakata, M.K.; Imamura, A. Real-time polymerase chain reaction assays for environmental DNA detection of three salmonid fish in Hokkaido, Japan: Application to winter surveys. Ecol. Res. 2019, 34, 237-242. [CrossRef]

95. Olds, B.P.; Jerde, C.L.; Renshaw, M.A.; Li, Y.Y.; Evans, N.T.; Turner, C.R.; Deiner, K.; Mahon, A.R.; Brueseke, M.A.; Shirey, P.D.; et al. Estimating species richness using environmental DNA. Ecol. Evol. 2016, 6, 4214-4226. [CrossRef]

96. Shaw, J.L.A.; Clarke, L.J.; Wedderburn, S.D.; Barnes, T.C.; Weyrich, L.S.; Cooper, A. Comparison of environmental DNA metabarcoding and conventional fish survey methods in a river system. Biol. Conserv. 2016, 197, 131-138. [CrossRef]

97. Evans, N.T.; Li, Y.; Renshaw, M.A.; Olds, B.P.; Deiner, K.; Turner, C.R.; Jerde, C.L.; Lodge, D.M.; Lamberti, G.A.; Pfrender, M.E. Fish community assessment with eDNA metabarcoding: Effects of sampling design and bioinformatic filtering. Can. J. Fish. Aquat. Sci. 2017, 74, 1362-1374. [CrossRef]

98. Li, Y.; Evans, N.T.; Renshaw, M.A.; Jerde, C.L.; Olds, B.P.; Shogren, A.J.; Deiner, K.; Lodge, D.M.; Lamberti, G.A.; Pfrender, M.E. Estimating fish $\alpha$-and $\beta$-diversity along a small stream with environmental DNA metabarcoding. Metabarcoding Metagenom. 2018, 2, e24262. [CrossRef]

99. Stoeckle, B.C.; Kuehn, R.; Geist, J. Environmental DNA as a monitoring tool for the endangered freshwater pearl mussel (Margaritifera margaritifera L.): A substitute for classical monitoring approaches? Aquat. Conserv. 2016, 26, 1120-1129. [CrossRef]

(C) 2020 by the authors. Licensee MDPI, Basel, Switzerland. This article is an open access article distributed under the terms and conditions of the Creative Commons Attribution (CC BY) license (http://creativecommons.org/licenses/by/4.0/). 